\title{
THE COMPLIANCE OF THE SOUTH AFRICAN SOCIAL SECURITY SYSTEM WITH THE INTERNATIONAL COVENANT ON ECONOMIC, SOCIAL AND CULTURAL RIGHTS
}

\author{
Yvette Basson \\ LLB LLM LLD \\ Lecturer, Faculty of Law \\ University of the Western Cape
}

\begin{abstract}
SUMMARY
The ratification of the International Covenant on Economic, Social and Cultural Rights by South Africa has resulted in the provisions thereof becoming binding on the South African legislature. The right to social security is entrenched in the ICESCR, which provides for the elements of a social security system that must be complied with by states. This article sets out what is required of states in terms of the right to social security in the ICESCR by way of crystallising the elements of a social security system. Thereafter, the South Africa social security system is compared to these elements to determine whether there is compliance with the right to social security in the ICESCR.
\end{abstract}

\section{INTRODUCTION}

The International Covenant on Economic, Social and Cultural Rights (ICESCR $)^{1}$ is one of the instruments that form the International Bill of Rights. ${ }^{2}$ One of the stated purposes of the ICESCR is the promotion of the general welfare of persons in a democratic society. ${ }^{3}$ The recognition that certain rights have an impact on the dignity of each person is an integral part of the ICESCR. To this end, the Preamble to the ICESCR provides that each person should be permitted to benefit from the exercise of his rights, which include economic, social, cultural, civil and political rights. ${ }^{4}$ Accordingly, the ICESCR makes provision for the realisation of numerous rights of the

\footnotetext{
The International Covenant on Economic, Social and Cultural Rights adopted and opened for signature, ratification and accession by General Assembly resolution 2200A (XXI) of 16 December 1966.

United Nations General Assembly Resolution 217 (1948) A/RES/217(III).

Art 4 of the ICESCR.

Preamble to the ICESCR.
} 
aforementioned categories. The content of the ICESCR includes provisions relating to the right to work, ${ }^{5}$ the right to social security ${ }^{6}$ and the right to an adequate standard of living. ${ }^{7}$

Approximately 165 countries have signed and ratified the ICESCR, which means that these countries are compelled to implement its provisions into their domestic law. ${ }^{8}$ However, a lack of ratification does not mean that countries that have only signed the ICESCR are unaffected by the provisions therein. Countries that have signed and not ratified the ICESCR are obliged to refrain from enacting laws which conflict with the provisions of the ICESCR. ${ }^{9}$

Until late 2014, South Africa was only a signatory to the ICESCR. ${ }^{10} \mathrm{~A}$ concerted campaign by numerous stakeholders resulted in the ratification of the ICESCR by South Africa on 12 January $2015 .{ }^{11}$ Upon ratification, South Africa became bound by the provisions in the ICESCR and has an obligation to domesticate the provisions therein. ${ }^{12}$ The role of South Africa as a State Party has now shifted from a passive one, in terms of which they were merely prevented from enacting laws in conflict with the provisions of the ICESCR, ${ }^{13}$ to an active one, in terms of which the provisions of the ICESCR

5 For e.g., Art 6(1) provides that "[t]he States Parties to the present Covenant recognize the right to work, which includes the right of everyone to the opportunity to gain his living by work which he freely chooses or accepts, and will take appropriate steps to safeguard this right".

6 Art 9 of the ICESCR provides that "[t]he States Parties to the present Covenant recognize the right of everyone to social security, including social insurance".

7 Art 11 of the ICESCR provides that "[t]he States Parties to the present Covenant recognize the right of everyone to an adequate standard of living for himself and his family, including adequate food, clothing and housing, and to the continuous improvement of living conditions. The States Parties will take appropriate steps to ensure the realization of this right, recognizing to this effect the essential importance of international co-operation based on free consent".

8 S 27(2) of the ICESCR provides that each state ratifying the ICESCR becomes bound by its provisions three months after such ratification. UN Committee on Economic, Social and Cultural Rights "Status of the International Covenant on Economic, Social and Cultural Rights" http://www.ohchr.org/Documents/lssues/HRIndicators/DatalCESCR.xls (accessed 2014-05-14).

9 Art 18 of the Vienna Convention on the Law of Treaties, 1969. Puta-Chekwe and Flood "From Division to Integration: Economic, Social and Cultural Rights as Basic Human Rights" in Merali and Oosterveld Giving Meaning to Economic, Social and Cultural Rights (2001) 47. CESCR was first invited to prepare general comments in 1987 - Economic and Social Council Resolution 1987/5. See also Tomuschat Human Rights: Between Idealism and Realism (2008) 190.

10 South Africa signed the ICESCR on 3 October 1994. UN Treaty Body Database https://tbinternet.ohchr.org/_layouts/15/TreatyBodyExternal/Treaty.aspx?CountrylD=162\&La $\mathrm{ng}=\mathrm{EN}$ (accessed 2020-02-04).

11 The stakeholders were, inter alia, Black Sash, the Community Law Centre at the University of the Western Cape and the Socio-economic Rights Institute of South Africa. See Dullah Omar Institute https://dullahomarinstitute.org.za/socio-economic-rights/internationalcovenant-on-economic-social-and-cultural-rights-icescr (accessed 2020-02-04).

12 Art 27(2) provides that the provisions of the ICESCR enter into force three months after the deposit of ratification documents by the state party.

13 S 39(2) of the Constitution of the Republic of South Africa, 1996 provides that international law must be taken into consideration when interpreting national legislation, irrespective of 
must now be incorporated into South African legislation. ${ }^{14}$ For purposes of this article, the provisions of the ICESCR relating to social security schemes is discussed.

\section{The right of access to social security in South Africa}

Section 27(1)(c) of the Constitution of the Republic of South Africa provides that "everyone has the right of access to social security, including, if they are unable to support themselves and their dependants, appropriate social assistance". This right is part of the collection of socio-economic rights found in the Bill of Rights. Section 7 of the Constitution emphasises this importance and further, provides important information on how the socioeconomic rights in the Bill of Rights are to be handled by the state. Section 7(2) provides that "[t]he state must respect, protect, promote and fulfil the rights in the Bill of Rights".

\section{According to Ngcobo CJ,}

"[t]his obligation goes beyond a mere negative obligation not to act in a manner that would infringe or restrict a right. Rather, it entails positive duties on the state to take deliberate, reasonable measures to give effect to all of the fundamental rights contained in the Bill of Rights". ${ }^{15}$

It was also found in Glenister $v$ President of the Republic of South Africa that, in interpreting the content of the obligation created by section 7(2), it was not necessary to prescribe exactly which steps the state has to take to meet its obligation in terms of the section. ${ }^{16}$ However, the chosen steps must be reasonable and effective, and must be steps that would be taken by a reasonable decision-maker in the circumstances. ${ }^{17}$ This means that any steps taken in relation to the realisation of the right of access to social security must be done in a manner that respects, protects, promotes and fulfils the right, and these steps must be reasonable.

According to the South African Human Rights Commission (SAHRC), the obligation to respect a right means that the state must not hinder the exercising of that right. ${ }^{18}$ This includes an obligation not to limit the enjoyment of a particular right already in existence. ${ }^{19}$ The protection of a right entails the state preventing violations of that right by third parties (the violation of the right by the state is already prohibited through the obligation to respect the right). ${ }^{20}$ The state must also promote rights in the Bill of Rights, which involves the provision of information about the right to persons

whether that international law has been ratified. This section does not place a positive obligation to incorporate unratified international law into national legislation.

14 Art 2 of the ICESCR.

15 Glenister v President of the Republic of South Africa 2011 (3) SA 347 (CC) par 105.

16 Glenister v President of the Republic of South Africa supra par 191.

17 Ibid.

18 SAHRC $7^{\text {th }}$ Report on Economic and Social Rights 2006-2009 (2009) vi.

19 Ibid.

20 SAHRC (2009) v. 
entitled to it. ${ }^{21}$ In other words, the state must educate persons about which rights they are entitled to and the scope and content of those rights. Finally, the obligation to fulfil rights obliges the state to take appropriate legislative and other measures which contribute to the full realisation of the rights in the Bill of Rights. ${ }^{22}$ The obligation to fulfil rights is somewhat curtailed by the principle that such fulfilment must be progressively realised using the resources available to the state. ${ }^{23}$

\section{Application of the right of access to social security}

The right of access to social security is guaranteed for "everyone" in terms of section 27(1)(c) of the Constitution. In the case of Khosa v Minister of Social Development, ${ }^{24}$ the Constitutional Court considered the meaning of the word "everyone" for purposes of the right of access to social security. Following the reasoning of the court in this case, it is implicit in the use of the word "everyone" that the right of access to social security is guaranteed to persons who are permanent residents or citizens of South Africa. ${ }^{25}$

According to section $27(2)$, "[t]he state must take reasonable legislative and other measures, within its available resources, to achieve the progressive realisation of these rights". ${ }^{26}$ The terms "reasonable measures", "available resources" and "progressive realisation" have specific meanings for the right of access to social security, which are discussed in the paragraphs hereafter.

Government of the Republic of South Africa $v$ Grootboom ${ }^{27}$ is the landmark case in relation to these terms. According to the Constitutional Court, in evaluating measures taken by the state to ensure access to social security the court is not concerned with the availability of "more desirable" measures, but rather with whether the measures taken were "reasonable". ${ }^{28}$ The court recognises that many different measures may be considered reasonable in any set of circumstances and, as long as the particular measures chosen can be considered reasonable in the circumstances, the requirement of reasonable measures is met. ${ }^{29}$

It was previously said that the right of access to social security cannot be enforced (or realised) upon demand, ${ }^{30}$ and this is echoed in the requirement

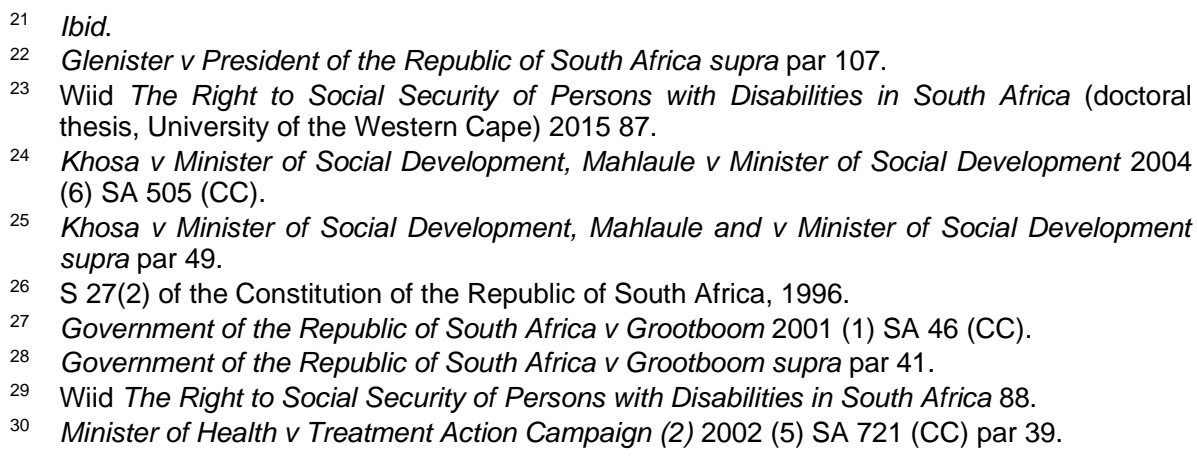


that the right be progressively realised. According to the Constitutional Court in the Grootboom case,

"The goal of the Constitution is that the basic needs of all in our society be effectively met and the requirement of progressive realisation means that the state must take steps to achieve this goal. It means that accessibility should be progressively facilitated: legal, administrative, operational and financial hurdles should be examined and, where possible, lowered over time." 31

Progressive realisation of social security includes, but is not limited to, increasing the level of coverage and benefits. ${ }^{32}$ This view is supported by the statement that achieving progressive realisation of socio-economic rights consists of more than increasing the finances allocated to the realisation of a particular right. ${ }^{33}$ The focus should rather be on how many people have actually been awarded the benefit attached to a particular socio-economic right.

The question of available resources raises the ever-present issue of social spending. Essentially, the right of access to social security is limited by the stipulation that the state is only compelled to provide social security benefits where it has the resources to do so. If the state is able to prove that it does not have the resources to meet its social security obligations, the resultant (internal) limitation of social security rights is justifiable. This does not mean that the state can entirely avoid its social security obligations merely by asserting that it does not possess adequate resources. ${ }^{34}$ In the Khosa case, the court stated that the limitation of the right of access to social security may be justifiable on the basis of a lack of resources, but the manner in which the existing resources are allocated must be consistent with the Bill of Rights in general. ${ }^{35}$

\section{THE RIGHT TO SOCIAL SECURITY IN THE ICESCR}

Article 9 of the ICESCR provides that "States Parties to the present Covenant recognize the right of everyone to social security, including social insurance." This article creates the right of individuals to social security, and a corresponding obligation on States Parties to provide such social security. However, Article 9 on its own does not provide much indication as to the scope and content of social security systems, beyond the allusion to social insurance.

In order to give content to the right to social security, the General Comments released by the Committee for Economic, Social and Cultural Rights (CESCR) need to be considered. The CESCR was established in

\footnotetext{
Government of the Republic of South Africa v Grootboom supra par 45.

Wiid The Right to Social Security of Persons with Disabilities in South Africa 92.

Ngxuza $v$ The Permanent Secretary, Department of Welfare, Eastern Cape 2001 (2) SA $609(\mathrm{E})$.

34 Olivier, Smit, Kalula (ed) Social Security: A Legal Analysis (2003) 76.

35 Khosa v Minister of Social Development, Mahlaule v Minister of Social Development supra par 45 .
} 
1985 for the purpose of monitoring the implementation of the ICESCR by States Parties. ${ }^{36}$ It is made up of 18 independent experts who are tasked with receiving state reports on the progress of implementation of the ICESCR and publishing their interpretation of the provisions of the ICESCR in the form of general comments. ${ }^{37}$

For purposes of social security, General Comment 19 provides information for States Parties to comply with Article 9 of the ICESCR.

\section{General Comment 19}

The right to social security is defined by the CESCR as the right to access and maintain benefits, whether in cash or in kind, without discrimination in order to ensure protection from a number of contingencies that result in a lack of work-related income, or unaffordable health care or insufficient family support.

According to General Comment 19, social security systems should be established in terms of the domestic law of each country and the administration thereof should be the responsibility of a public authority. ${ }^{38}$ This means that it is up to each State Party to decide how to administer its own social security system, and that such administration must be transparent. The CESCR also confirms that there are a number of contingencies for which any social security system should provide coverage. ${ }^{39}$ These contingencies are sickness, disability, maternity, employment injury, unemployment, old age or death of a family member. ${ }^{40}$ However, the General Comment does not provide more specific examples of events leading to loss of income resulting from these contingencies, nor does it refer to any monetary amounts which may be provided to persons affected by such contingencies. ${ }^{41}$

In order to inform the approach of state parties in implementing the right to social security, the General Comment requires states parties to respect, protect and fulfil the right to social security. ${ }^{42}$ This echoes the obligation to respect, protect, promote and fulfil the right of access to social security in the

36 The implementation of the provisions of the ICESCR by states that have ratified it is monitored by the Committee on Economic, Social and Cultural Rights (CESCR). This committee is also responsible for releasing general comments on the ICESCR in order to clarify the obligations created by its various provisions. The CESCR was established in 1985 in terms of the Economic and Social Council Resolution 1985/17.

37 United Nations Human Rights Office of the High Commissioner "Committee on Economic, Social and Cultural Rights" https://www.ohchr.org/EN/HRBodies/CESCR/Pages/CESCR Intro.aspx (accessed 2020-02-21).

38 General Comment 19 Part II.

39 General Comment 19 Item 2.

40 General Comment 19 Item 2.

41 Scruggs and Zimmerman "Implementation of the Human Right to Social Security Around the World. A Preliminary Empirical Assessment of National Social Protections Laws" in Minkler (ed) The State of Economic and Social Human Rights (2013) 119.

42 Vonk "The Fundamental Right of Social Assistance: a Global, a Regional (Europe and Africa) and a National Perspective (Germany, the Netherlands and South Africa)" 2019 21(3) European Journal of Social Security 219228. 
Constitution, although the explanations of each term are not identical. In respecting and protecting the right to social security, it has been suggested that the state must not only provide legislative protection to existing private and collective social security schemes but also that non-state social security schemes must be established. ${ }^{43}$ The fulfilment of the right to social security is more straightforward, in that the state party is merely required to have a legislative framework in place for a social security system. ${ }^{44}$

General Comment 19 provides for basic principles which must be present in any social security system. ${ }^{45}$ In the following paragraphs these basic principles as well as the obligations discussed above are explained and applied to the South African social security system in order to gauge whether South Africa's social security system complies with them.

\section{INDICATORS FOR COMPLIANCE WITH THE ICESCR}

From the discussion of General Comment 19, several indicators can be crystallised that can be used to determine whether a country's social security system meets the requirements established by the ICESCR. These indicators are:

- the existence of a social security system

- the administration of such social security system by a public authority

- the coverage of a minimum of nine named contingencies

- the level of coverage provided by the social security system

- the level and duration of benefits provided

- the use of benefits in the realisation of other rights in the ICESCR

The Office of the High Commissioner of the United Nations summarises the key elements of the right to social security as availability, adequacy, affordability and accessibility. ${ }^{46}$ The implementation of the right to social security must therefore be informed by these three principles. ${ }^{47}$ Each of these elements can be linked to one of the indicators named above.

\section{The existence of a social security scheme}

This indicator could also be called the availability of a social security system. This indicator is arguably the easiest one to satisfy, in that all that need be proved is that a social security system providing benefits is in place. This is also reminiscent of the requirement to fulfil the right to social security in

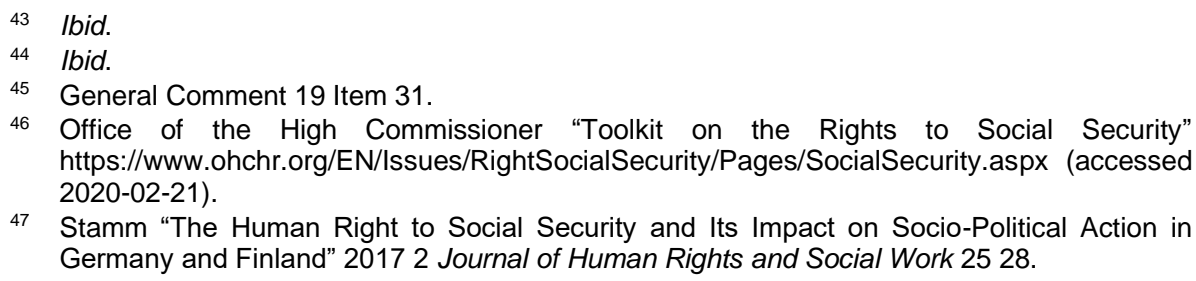
https://www.ohchr.org/EN/Issues/RightSocialSecurity/Pages/SocialSecurity.aspx (accessed 2020-02-21).

47 Stamm "The Human Right to Social Security and Its Impact on Socio-Political Action in Germany and Finland" 20172 Journal of Human Rights and Social Work 2528. 
General Comment 19, which also only requires that a legislative framework for social security be in place. ${ }^{48}$ The system may consist of a single scheme or a variety of schemes; 49 the accessibility and adequacy of these schemes becomes relevant when applying the other indicators.

In terms of section 27 of the Constitution of the Republic of South Africa, everyone has a right of access to social security. 50 There is thus a constitutional basis for the social security system in South Africa, subject to certain limitations and qualifying criteria. In addition, numerous pieces of legislation give effect to this constitutional right. These include the Social Assistance Act, ${ }^{51}$ Unemployment Insurance Fund Act, ${ }^{52}$ Compensation for Occupational Injuries and Diseases Act and the Pension Funds Act. ${ }^{53}$ The Social Assistance Act makes provision for social grants administered by the State, and the other legislation mentioned establishes and provides structure for various social insurance schemes. The social security system therefore exists and consists of multiple schemes as envisaged by the UN High Commissioner.

\section{Administration by a public authority}

The ICESCR requires that the social security system of a member state be administered by a public authority. Neither the ICESCR nor the General Comment relating to social security provides a definition of "public authority". However, a public authority is defined as any government or public institution at national, regional or local level. It is submitted that a government department or institution that performs a public function and is financially accountable to a national or regional institution would be appropriate for administration of social security in terms of the ICESCR.

This indicator ties in with the obligation to protect the existing social security system. Through requiring the administration of social security schemes to be transparent and publicly accountable, a number of harmful behaviours affecting the funding of social security may be prevented. Since State Parties must protect their social security systems and considering that these schemes are often funded by public monies, requiring that the administrating authorities subject themselves to public scrutiny is particularly appropriate.

48 Vonk 2019 European Journal of Social Security 219228.

49 Office of the High Commissioner https://www.ohchr.org/EN/Issues/RightSocialSecurity/ Pages/SocialSecurity.aspx (accessed 2020-02-21).

50 S 27(1)(c) of the Constitution of the Republic of South Africa, 1996.

5113 of 2004.

5263 of 2001.

5324 of 1956. 


\section{Administration of social assistance}

The administration of social assistance in South Africa is the responsibility of the Department of Social Development, ${ }^{54}$ which is a state department under the leadership of the Minister of Social Development. In terms of national legislation, the Minister may delegate the administration of social assistance, ${ }^{55}$ and has done so. The delegation of responsibility to the South African Social Security Agency (SASSA) was done in terms of the South African Social Security Agency Act in 2004. ${ }^{56}$ The express purpose of SASSA is to act as the sole agency involved in the management, administration and payment of social assistance in South Africa. ${ }^{57}$ Since SASSA is subject to the provisions of the Public Finance Management Act 58 which regulates the management of finances in national and provincial government and is a juristic person, ${ }^{59}$ this satisfies the requirement relating to administration by a public authority.

\section{Administration of social insurance}

Social insurance in South Africa is somewhat fragmented, in that there are a number of available schemes and each of these is run by a different institution. The major social insurance schemes are the Unemployment Insurance Fund, the Compensation for Occupational Injuries and Diseases Fund and retirement schemes. One can therefore not say that social insurance is administered by a public authority in its entirety without looking at the management of each scheme in turn.

The Unemployment Insurance Fund (UIF) was established in terms of the Unemployment Insurance Act ${ }^{60}$ in 2001. The UIF provides benefits for persons who were employed and making contributions to the UIF and who are no longer able to work as a result of contingencies such as pregnancy, illness and dismissal. ${ }^{61}$ The entity responsible for the administration and management of the fund is the Department of Labour, which is a state department forming part of the South African government. ${ }^{62}$ The UIF is also subject to the provisions of the Public Finance Management Act. ${ }^{63}$ The UIF thus satisfies the requirement of administration by a public authority.

The Compensation for Occupational Injuries and Diseases Fund (COIDA Fund) was established in terms of the Compensation for Occupational

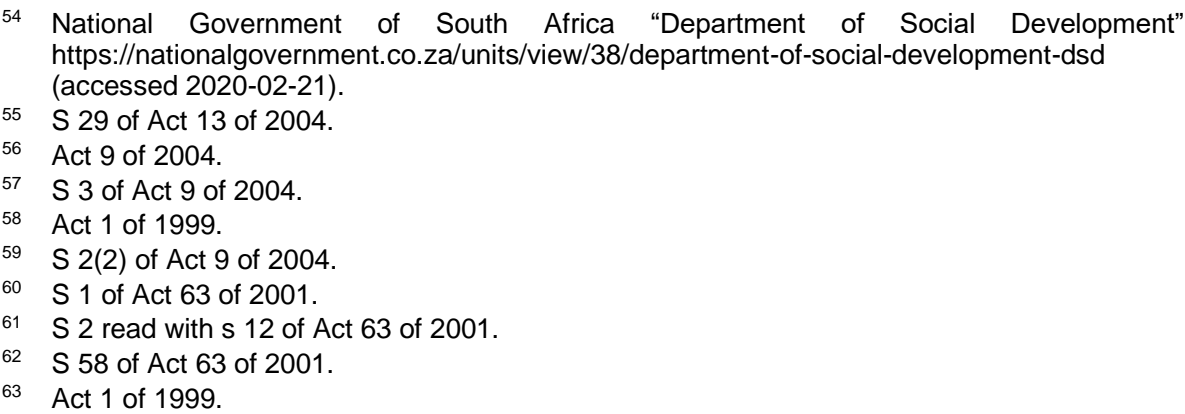


Injuries and Diseases Act (COIDA) in 1993.64 The purpose of the COIDA fund is to compensate workers who are injured or become ill in the course of their employment and are unable to work because of such injury or illness. ${ }^{65}$ The COIDA Fund is also administered by the Director-General of the Department of Labour, ${ }^{66}$ and as such is administered by a public authority.

Retirement schemes in South African are numerous and varied - there are over 5000 active retirement funds in South Africa. ${ }^{67}$ Each of these funds has its own board of trustees and management. However, these funds are subject to the provisions of the Pension Funds Act, ${ }^{68}$ which provides for the regulatory framework within which each of these funds must operate. In addition, retirement funds are subject to the rules of the Financial Services Conduct Authority, ${ }^{69}$ which is empowered to investigate and regulate the conduct of financial service providers in South Africa, including retirement funds. ${ }^{70}$ While there is no single administrator for retirement funds in South Africa, the regulatory framework established by the Pension Funds Act may be considered a public authority for purposes of this discussion.

Since each of the major social insurance schemes in South Africa is managed by a public agency, it is submitted that social insurance as a whole complies with the ICESCR requirement of management by a public authority and the obligation to protect social security schemes.

\section{Coverage of contingencies}

According to General Comment 19, the social security systems of States Parties should provide coverage for contingencies from the nine principal branches of social security. ${ }^{71}$ These branches are health care, sickness, old age, unemployment, employment injury, family and child support, maternity, disability, and survivors and orphans. ${ }^{72}$

Social assistance in South Africa provides social grants for persons who are unable to provide for their own maintenance needs. ${ }^{73}$ There are grants payable to persons who are unable to meet their own maintenance needs as a result of disability, old age and for families with children under 18 and families with disabled children who are unable to meet the financial needs of those children. ${ }^{74}$ Social insurance provides financial assistance for persons who have become unemployed as a result of illness, maternity, dismissal, retrenchment, occupational injury, occupational diseases and for survivors in

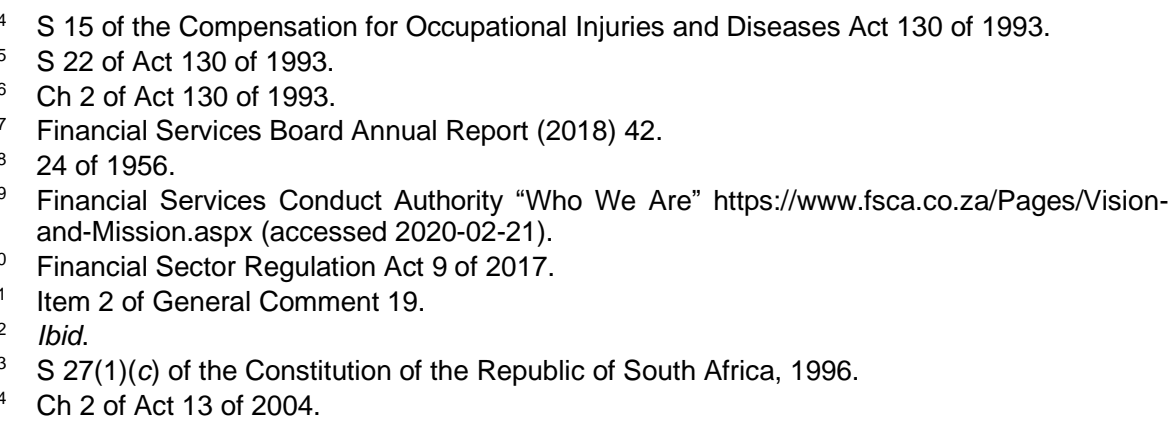


the event of the death of the breadwinner. The UIF is the source of many of these benefits. ${ }^{75}$ Benefits in the form of partial income replacement for persons who are injured or become ill in the course of their employment are payable from the COIDA Fund. ${ }^{76}$

Between the contingencies covered by social grants and social insurance schemes, all the contingencies specified by the CESCR are provided for in the South African social security landscape.

\section{Level of coverage}

This indicator refers to the reach of social security. Put in simpler terms, the number of people covered by social security needs to be assessed in order to establish whether such coverage is adequate or not. This component of the right to social security ties in with the element of accessibility as specified by the UN High Commissioner.

\section{Coverage of social assistance}

As per section 27(1)(c) of the Constitution, the right of access to social security includes social assistance for persons who are unable to provide for their own maintenance needs. ${ }^{77}$ The right of access to social assistance is thus inclusive as indicated by the use of the word "everyone", ${ }^{78}$ but qualified through providing that persons only gain access to social assistance if they are unable to provide for their own maintenance needs. This qualification takes the form of the use of a means test applied to persons applying for social assistance..$^{79}$ The purpose of the means test is to prevent persons receiving social grants when their financial needs are being met through their own endeavours. ${ }^{80}$ It has been argued that the means test should be abolished and that social assistance should be awarded to any person applying for it.81 It is submitted that this argument is flawed, since it would place an undue burden on an already financially strained state. As of February 2019, there were approximately 18 million social grant recipients in South Africa. ${ }^{82}$ This number was higher than the number of persons

75 The UIF pays benefits for maternity, adoption, illness, dismissal, retrenchment and the death of the breadwinner. See Parts B-F of Act 63 of 2001.

76 S 22 of Act 130 of 1993.

77 S 27(1)(c) of the Constitution of the Republic of South Africa, 1996.

78 The word "everyone" refers to South African citizens and permanent residents as decided by the Court in Khosa $v$ Minister of Social Development, Mahlaule $v$ Minister of Social Development supra par 49.

79 Ss $5(2)(a)$ and $(b)$ of 13 of 2004.

80 Economic Policy Research Institute "Social Security Take-Up and the Means Test in South Africa” (2001) EPRI Research Paper \#24 3.

81 Reports of the Taylor Committee into a Social Security System for South Africa (2002) 24; Nyenti and Mpedi "The Impact of SADC Social Protection Instruments on the Setting Up of a Minimum Social Protection Floor in South African Countries" 2012 15(1) Potchefstroom Electronic Law Journal 244269.

82 Minister of Finance Budget Speech 2019/2020 https://www.sanews.gov.za/southafrica/increased-allocations-grants-education-and-health (accessed 2020-02-21). 
employed in formal employment at that time ${ }^{83}$ and comprised approximately 30 per cent of the total population. ${ }^{84}$ It is submitted that social assistance coverage in South Africa is currently in compliance with Article 9 of the ICESCR in relation to the extent of coverage, since such a large number of persons are in receipt of a social grant.

It must be noted that this indicator is subject to the internal limitation in section 27 of the Constitution, which provides that the right of access to social security is subject to available resources. ${ }^{85}$

Since social assistance is funded through general revenue (which includes income tax), ${ }^{86}$ the amount that is available for distribution through social assistance is limited. This limitation is as a result of the low levels of formal employment in the country, ${ }^{87}$ which consequently results in a relatively low number of persons paying income tax. The less tax paid by those who are in formal employment, the less money there is available for social assistance grants. The state may thus claim that the current number of social assistance grant recipients and the concomitant social spending is the best that can be done within the currently available resources.

\section{Impact of COVID 19 on social assistance}

In April 2020, President Cyril Ramaphosa announced a range of measures that would benefit social grant recipients during the nationwide lockdown in response to the international outbreak of COVID-19.88 These measures include the availability of a lesser used social grant, called social relief of distress ${ }^{89}$ and the temporary increase in the amounts received by all existing social grant recipients. The source of funds for these increases was not the general revenue used for the standard social grants but was an amount that was re-directed from other parts of the budget allocated to other expenditure..$^{90}$ In addition, funds were made available from other state administered funds such as the UIF and sources from local and international sources. ${ }^{91}$

The rapid response of the state to the needs of social assistance recipients is indicative of the state's commitment to providing financial assistance to those in dire need and is to be commended. However, it is

83 Quarterly Labour Force Survey Q2 2019 provides that there were 11220000 people in formal in employment from January to March 2019.

84 Statistics South African Mid-Year Population Estimates 2019 estimates that the mid-year population was 58,78 million.

85 S 27(2) of the Constitution.

86 Strydom (ed) Essential Social Security (2006) 7.

87 The Statistics SA Quarterly Labour Force survey (2019) estimates the number of people in formal, non-agricultural employment at 10142000 .

88 Speech made by President Cyril Ramaphosa (21 April 2020) https://www.gov.za/speeches/ president-cyril-ramaphosa-additional-coronavirus-covid-19-economic-and-social-relief (accessed 2020-05-23).

89 LAWSA XIII Social Security: Core Elements par 188.

90 Speech made by President Cyril Ramaphosa https://www.gov.za/speeches/president-cyrilramaphosa-additional-coronavirus-covid-19-economic-and-social-relief.

91 lbid. 
submitted that the increased amounts made available temporarily do not mean that there is more money available to social grant recipients under normal circumstances. As indicated above, the funds used for the new and increased social grants are not sourced from general revenue, which is the dedicated source of funds for social grants. These funds were made available through emergency and temporary measures and cannot be used to make the argument that the state is not using its available resources to increase the amounts paid to social grant recipients in normal circumstances.

\section{Coverage of social insurance}

It is more complicated to determine the exact level of coverage of social insurance schemes in South Africa. Social insurance consists of a number of schemes that may have no relation to each other, save that they can only be accessed through employment. ${ }^{92}$ The three primary social insurance schemes are the UIF, the COIDA Fund and retirement funds.

The pre-requisite of employment makes social insurance schemes exclusive in nature, since the unemployment rate in South Africa at the end of 2019 was $29.1 \% .{ }^{93}$ This means that a third of the working age population has no access to social insurance. Further, these schemes are only accessible to certain categories of employees and exclude workers in informal employment, casual workers and often government employees and members of the military also. ${ }^{94}$ Considering that so many persons are excluded from social insurance, it is submitted that the level of coverage currently provided does not comply with Article 9 of the ICESCR.

\section{Level and duration of benefits}

The level and duration of benefits provided by a social security scheme must be adequate and must be provided as long as the individual is negatively affected by the particular contingency they are receiving benefits for. This means that the benefits provided must be enough to meet the recipients' basic needs and the benefits should not be ceased while the recipient needs them.

\section{Level of benefits provided by social assistance}

The level of benefits refers to the amount of money paid to recipients of such benefits. In order to satisfy this requirement, the amount paid must be

92 Olivier and Mpedi "The Extension of Social Protection to Non-Formal Sector Workers Experiences from SADC and the Caribbean" 200519 Zeitschrift fur auslandisches und internationals Arbetis- und Sozialrecht (ZIAS) 150152.

93 Statistics South Africa Quarterly Labour Force Survey Q4 2019 http://www.statssa.gov.za/?p=12948 (accessed 2020-02-21).

94 For e.g., domestic workers and self-employed persons are excluded from the COIDA Fund in terms of $\mathrm{s} 1$ (xix) of 130 of 1993, and migrant and government workers are excluded from the UIF in terms of s 3(1) of 63 of 2001. 
adequate. What is meant by adequate is not easy to establish, considering that there are many factors contributing towards the financial needs of persons negatively affected by the named contingencies. It is submitted that, in the South African context, this amount should allow a grant recipient to provide for their own maintenance needs, since this is the primary qualifier for social assistance in the Constitution. For purposes of this article, the amounts paid through social assistance are provided and then analysed to gauge whether these are "adequate".

\section{Minimum wage as an indicator of adequacy}

Social grants for older persons and persons with disabilities provide the same amount to recipients (this is not taking into consideration any supplementary grants such as the grant in aid). As of April 2020, this amount is R1860 per month per recipient ${ }^{95}$ (excluding the additional temporary amount payable as a result of the COVID19 outbreak). ${ }^{96}$ From this amount, a recipient is expected to provide for all their daily needs, such as food, rent and electricity. ${ }^{97}$

As of 1 January 2019, the National Minimum Wage in South Africa is R20 per hour. ${ }^{98}$ This amount was increased to R20.76 for employees, effective 1 March 2020.99 The primary aim of introducing a minimum wage is to address the extreme levels of income inequality in South Africa. ${ }^{100}$ Based on a work week of 40 hours (excluding any overtime that may be required), this equates to approximately R43 000 per annum. A person earning a minimum wage therefore earns approximately R3600 per month. This means that a social grant recipient is expected to meet their own maintenance needs with slightly more than half the amount that is considered adequate as a minimum wage. It is submitted that this amount cannot be considered adequate for purposes of meeting the requirements of the ICESCR.

However, one must still consider the impact of the internal limitations on the right of access to social security found in section $27(2)$, which are that the right must be realised progressively and within the available resources. As discussed above, the resources available to the state are finite and do not leave much room for increasing social grant amounts. The issue of progressive realisation is addressed through the annual increase of the

95 Minister Tito Mboweni Budget Speech (2020) https://www.gov.za/BudgetSpeech2020 (accessed 2020-05-23).

96 South African Government "Social Grants - Coronavirus COVID19" https://www.gov.za/ coronavirus/socialgrants (accessed 2020-05-23).

97 South Africa does have free basic healthcare, so this expense is not necessarily meant to be covered by the grant amount. However, it is widely known that the public healthcare system is rife with problems and may not be reliable. Unfortunately an in-depth discussion of public healthcare in South Africa is beyond the scope of this article, but the existence and availability of such a system must be noted for purposes of the amount payable in terms of social grants.

98 S 6(6) read with Schedule 1 of the National Minimum Wage Act 9 of 2018.

99 This increase was made in terms of $\mathrm{s} 6$ of Act 9 of 2018, which requires an annual review of the minimum wage and allows for adjustments to the minimum wage amount.

100 Preamble to Act 9 of 2018. 
amounts payable to social grant recipients. ${ }^{101}$ Each year in the annual budget speech, social grant amounts are increased by a small amount, usually less than R100 per social grant recipient. Considering that the concept of progressive realisation only requires that the state take steps to increase the level of benefits payable, it can thus be said that the annual increase to social grants amounts to progressive realisation. The state is thus progressively realising the right of access to social assistance through this annual increase, albeit that such realisation is slow because of the small amount by which the grant is increased.

The question, then, is whether the current inadequate amount is justified by the clear progressive realisation and the limitation of available resources. It is submitted that the low amount payable is, in fact, justified through an examination of these limitations. As mentioned previously, state expenditure on social grants is already substantial and the growing number of social grant recipients makes increasing the amount payable infeasible. In addition, the state is meeting its obligation to progressively realise the right of access to social assistance through annual increases in social grant amounts.

Despite the initial finding that the social grants in South Africa are not compliant with the ICESCR, it is submitting that the amount paid is justifiable by the requirements of the Constitution, which take precedence over the provisions of international law.

\section{Level of benefits provided by social insurance}

The benefits payable through social insurance schemes are not only extremely varied, but also tailored to each individual recipient. In the case of UIF benefits, the amount payable depends on the amount the employee has contributed to the UIF and for how long they made contributions. ${ }^{102}$ The actual individual benefit is paid on a sliding scale based on the recipients' salary. ${ }^{103}$ This means that the more an employee earns, the smaller percentage of their salary will be paid in UIF benefits. COIDA Fund benefits are calculated on an individual basis and depend upon the nature and extent of the illness or injury experienced by the employee. ${ }^{104}$ Retirement fund benefits depend on the amount and duration of contributions made by the recipient and, in some cases, tax must be paid on benefits received. ${ }^{105}$ For these reasons, it is not possible to establish whether social insurance payments as a whole are adequate in South Africa. Such an in-depth analysis would have to take place on a case by case basis for each scheme and is therefore beyond the scope of this article.

101 Government of the Republic of South Africa v Grootboom supra par 45.

$102 \mathrm{~S} 12$ of 63 of 2001.

$103 \mathrm{~S} 13$ of 63 of 2001 .

104 Ch IV of the Compensation for Occupational Injuries and Diseases Act 130 of 1993.

105 Whether tax is payable depends on the amount received - see South African Revenue Service "Retirement Lump Sum Benefits" https://www.sars.gov.za/Tax-Rates/IncomeTax/Pages/Retirement-Lump-Sum-Benefits.aspx (accessed 2020-02-23). 


\section{Duration of social assistance benefits}

In terms of social assistance, the social grant is payable for as long as the recipient is unable to meet their financial needs. ${ }^{106}$ The right of access to social security is thus qualified, and the use of a means test has been implemented in order to determine the financial need of applicants for social assistance. ${ }^{107}$ If an applicant for (or recipient of) a social grant earns money in excess of a specified amount, they become ineligible for the social grant and the grant will either not be awarded, ${ }^{108}$ or, in the case of a person already receiving a grant, the payment of the grant will cease. ${ }^{109}$ The threshold for income is currently R82 400 per annum for single persons and R164 880 for married persons. ${ }^{110}$ An applicant or recipient is thus permitted to have an income, as long as the income does not exceed these amounts. Any income received will cause the amount received from the social grant to be adjusted pro rata. ${ }^{111}$ The principle applicable here is that once income exceeds these amounts, a recipient is no longer unable to meet their own maintenance needs and the contingency has therefore effectively ended. ${ }^{112}$

In addition to the use of the means test, a social grant will also lapse if the contingency for which it is paid is no longer applicable. In particular, if a recipient of a disability grant is no longer considered disabled and declared medically fit to work, the grant will lapse. ${ }^{113}$ Similarly, if a social grant is paid in respect of a child, the grant will lapse when the child reaches the age of majority. ${ }^{114}$

A further example of social assistance benefits only being paid while needed is the availability of the temporary social relief of distress grant made available to persons affected by the outbreak of COVID-19 who have consequently lost income. ${ }^{115}$ As of May 2020, the social relief of distress grant will be payable to successful applicants for 6 months. ${ }^{116}$ The increases in social grant amounts already being paid are also effective for 6 months. ${ }^{117}$

106 Olivier et al Social Security: A Legal Analysis 327.

107 Ibid.

108 Economic Policy Research Institute "Social Security Take-Up and the Means Test in South Africa" EPRI Research Paper 243.

109 In terms of $s$ 14(5) of Act 9 of 2004, a recipient of a social grant must inform SASSA of any material changes in their circumstances after applying for the grant. In terms of $s$ 17(1), any person in receipt of amounts they are not entitled can be compelled to repay those amounts to SASSA. It is also an offence to withhold such information and an offence to receive a social grant while knowing that one is not entitled thereto in terms of $\mathrm{s} 21$.

110 SASSA "You and Your Grant 2019/2020" (2019) https://www.sassa.gov.za/Pages/GrantBooklets.aspx (accessed 2020-02-23) 7.

111 lbid.

112 Wiid The Right to Social Security of Persons with Disabilities in South Africa 183.

113 SASSA "Disability Grant" https://www.sassa.gov.za/Documents/GrantsDocuments/Disability-Grant.pdf (accessed 2020-02-23).

114 SASSA "Child Support Grant" https://www.sassa.gov.za/Documents/GrantsDocuments/Child-Support-Grant.pdf (accessed 2020-02-23).

115 Minister Tito Mboweni Budget Speech https://www.gov.za/BudgetSpeech2020.

116 South African Government 'Social Grants - Coronavirus COVID19' https://www.gov.za/coronavirus/socialgrants (accessed on 23/05/2020).

117 South African Government https://www.gov.za/coronavirus/socialgrants. 
The state is thus clearly cognisant of the need to provide social assistance when it is most needed by recipients.

It is thus submitted that social assistance (both in the form of temporary grants and permanent grants) therefore does provide benefits for the duration of the financial need of the recipient and meets the requirement of adequate duration of benefits.

\section{Duration of social insurance benefits}

The social insurance schemes in South Africa are not means tested. This means that there are no income thresholds attached to the receipt of social insurance benefits. However, certain social insurance benefits may cease before the contingency has ended. For example, UIF benefits paid to an unemployed person may be exhausted before the recipient has secured further employment. ${ }^{118}$ This is also the case where UIF benefits are paid to and exhausted by a recipient who is no longer working as a result of illness or incapacity who has not yet been able to return to work. Since UIF benefits may not be payable for the entirety of the period that a person is unemployed, it may appear as though the duration of benefits is not adequate. However, it must be borne in mind that UIF benefits are funded through contributions by the employee and their employer and are capped at a certain amount. ${ }^{119}$ The duration of UIF benefits is thus a legislative principle and is aimed at encouraging recipients to secure employment and providing benefits beyond this is not possible.

In the case of COIDA Fund benefits, the duration of benefits depends on the nature of the illness or injury experienced by the recipient of benefits. Employees with permanent disablements will receive benefits for life; ${ }^{120}$ those with temporary disablements receive benefits for the duration of the illness or injury. ${ }^{121}$ It is submitted that the duration of COIDA benefits is adequate.

Finally, retirement fund benefits are paid once a member of a retirement fund reaches retirement age. Retirement fund benefits can be paid as a pension or as a lump sum. ${ }^{122}$ In the case of a pension, one third of retirement fund savings is paid out immediately at retirement and the balance of the amount is usually payable until the death of the recipient. ${ }^{123} \mathrm{~A}$ provident fund pays out in one lump sum upon the retirement of the employee. ${ }^{124}$ It is submitted that the provision of benefits until death is adequate. In the case of a lump sum, the recipient must manage their finances themselves in order to ensure that the amount will cover their

\footnotetext{
18 Ss 15 and 16 of Act 63 of 2001.

$19 \mathrm{~S} 13$ of Act 63 of 2001 provides that a maximum of 238 days benefit is payable.

120 S 49 read with Schedule 2 of Act 130 of 1993.

121 lbid.

122 The South African Labour Guide "Pension and Provident Funds" https://www.labourguide.co.za/general/499-pension-and-provident-funds (accessed 202002-24).

$123 \mathrm{~S} 1$ of Act 24 of 1956.

124 Ibid.
} 
financial needs for the rest of their life. Since there is no oversight in this management of funds, the longevity of this lump sum is entirely individual and adequacy can therefore not be assessed.

\section{Use of benefits to realise other rights}

The United Nations recognises that all rights are interrelated, ${ }^{125}$ and that the realisation of one of these rights could contribute towards the full realisation of other rights. The provision of financial assistance through social security schemes to persons with disabilities creates opportunities for social inclusion and better participation in society. ${ }^{126}$ For example, the provision of adequate financial assistance may enable a person with a disability to make use of rehabilitation services or create the opportunity for further education. The provision of adequate social security benefits is thus vital for a number of related rights which are provided for in the ICESCR. In the case of the right to social security, the clearest link exists between it and the right to an adequate standard of living. ${ }^{127}$

\section{Social assistance}

The right to social security has been recognised as a chief contributor to achievement to the right of an adequate standard of living guaranteed in terms of international law. ${ }^{128}$ However, an incomplete realisation of the right to social security would not result in as great a contribution towards the realisation of other rights. ${ }^{129}$ Considering that that the benefits provided by social grants are not sufficient to meet the maintenance needs of social grant recipients, ${ }^{130}$ it is submitted that social assistance is not sufficient to realise the right to an adequate standard of living as envisaged in international law, and may have a similar effect on the realisation of other rights related to the right to social security.

It must be noted that financial assistance does not comprise the entirety of a social security system. Goods and services such as free utilities, subsidised housing and free healthcare also form part of the broader concept of social protection. ${ }^{131}$ In South Africa, many basic goods and services are either free or substantially subsidised, although the standard of

125 Office of the High Commissioner "Your Human Rights" https://www.ohchr.org/EN/Issues /Pages/WhatareHumanRights.aspx (accessed 2020-02-24).

126 Item 59 of General Comment 19.

127 Item 28 of General Comment 19.

128 Wiid The Right to Social Security of Persons with Disabilities in South Africa 150.

129 Office of the High Commissioner https://www.ohchr.org/EN/lssues/Pages/ WhatareHumanRights.aspx.

130 The submission that the amount provided to social grant recipients is justified in terms of the Constitution in paragraph 3.5.1 above does not affect the reality that the amount provided does not facilitate the realisation of an adequate standard of living of these recipients.

131 Report of the Committee of Inquiry into a Comprehensive System of Social Security for South Africa (2002) Transforming the Present - Protecting the Future 41. 
these services is not necessarily adequate. ${ }^{132}$ Unfortunately a full discussion of the adequacy of these measures is beyond the scope of this article. Nonetheless, it is submitted that the social assistance amount payable that is the subject of this discussion is not sufficient to realise an adequate standard of living either on its own, or in conjunction with sub-par additional goods and services.

\section{Social insurance}

An assessment of whether social insurance benefits are being used to realise an adequate standard of living for persons with disabilities is not as simple. This is because each recipient of COIDA Fund and UIF benefits receives a benefit that is based on their salary, which means benefits are highly individualised. ${ }^{133}$ The level of social insurance benefits available may contribute greatly towards the realisation of an adequate standard of living for a person in receipt thereof. However, while social insurance schemes are inaccessible to large numbers of persons as a result of unemployment in South Africa, ${ }^{134}$ the level of benefit is irrelevant. It is thus submitted that social insurance benefits are not currently contributing towards the achievement of an adequate standard of living since so many are excluded from social insurance schemes.

\section{4}

REPORTING AND ENFORCEMENT MECHANISMS

In terms of Article 16 of the ICESCR,

"The States Parties to the present Covenant undertake to submit in conformity with this part of the Covenant reports on the measures which they have adopted and the progress made in achieving the observance of the rights recognized herein."

This means that States Parties are required to compile and submit reports on the status of the implementation of the provisions of the ICESCR periodically. South Africa submitted the initial report in $2017,{ }^{135}$ as required by Article 17 of the ICESCR. The section on the right to social security is woefully inadequate. The report includes only two pages of information related to social security in South Africa, and merely states selected statistics related to social assistance without attempting to show the adequacy of the benefits provided through social security. ${ }^{136}$ Essentially, the

132 See generally Statistics South Africa The State of South Africa: In-Depth Analysis of the Community Survey 2016 data (2016).

133 Wiid The Right to Social Security of Persons with Disabilities in South Africa 239.

134 See par 3.4.2 above for a discussion of the impact of unemployment on access to social insurance.

135 Initial Report of South Africa on the International Covenant on Economic, Social and Cultural Rights (2017) https://tbinternet.ohchr.org/layouts/15/treatybodyexternal /Download.aspx?symbolno=E\%2fC.12\%2fZAF\%2f1\&Lang=en (accessed 2020-02-24).

136 Initial Report of South Africa on the International Covenant on Economic, Social and Cultural Rights https:/ttbinternet.ohchr.org/_layouts/15/treatybodyexternal/Download.aspx? symbolno=E\%2fC. $12 \% 2 f Z A F \% 2 f 1 \&$ Lang=en 31 . 
report only confirms the existence of social assistance and the institutions involved in the administration thereof.

The report omits social insurance, save for one recommendation relating to the extension of coverage of the UIF. ${ }^{137}$ While reporting on social insurance is problematic, the omission of one of the two main branches of social security is not acceptable for reporting purposes. It is clear upon reading the section on social security in the country report that much more information and analysis must be provided in order to establish whether the South African social security system meets the requirements of the ICESCR. A mere statement of information relating to social assistance is not enough.

The lack of information in the section on social security has been noted and addressed by the CESCR in its "Concluding Remarks" on the Country Report. ${ }^{138}$ The CESCR has also made a number of recommendations relating to social assistance, including the increasing of the monthly amount paid and the abolition of the means test for certain applicants. ${ }^{139}$ It is respectfully submitted that the Concluding Remarks do not provide enough information in order to rectify the current problems with social assistance, and that the recommendations relating to social assistance are too vague to be meaningful at this stage. If South Africa does not implement the Concluding Remarks, it is unclear what the sanctions would be. The current reporting and monitoring mechanisms appear to be somewhat toothless, in that the CESCR cannot compel a State Party to comply with its recommendations. Real change requires firmer and more harsh consequences for continued non-compliance with the ICESCR and the Concluding Remarks made by the CESCR.

\section{CONCLUSION AND RECOMMENDATIONS}

From the above discussion, the duty of South Africa to comply with the provisions of the ICESCR in relation to social security has been established. ${ }^{140}$ These requirements are the existence of a social security system; the administration of such social security system by a public authority; the coverage of a minimum of nine named contingencies; the level of coverage provided by the social security system; the level and duration of benefits provided; the use of benefits in the realisation of other rights in the ICESCR.

\section{Conclusion}

Upon critical analysis of the elements of the right to social security in the ICESCR, it becomes apparent that South Africa's current social security

\footnotetext{
137 CESCR "Concluding Remarks on the Initial Report of South Africa" (2018) https://tbinternet.ohchr.org/_layouts/15/treatybodyexternal/Download.aspx?symbolno=E\%2f C.12\%2fZAF\%2fCO\%2f1\&Lang=en (accessed 2020-02-24) 9.

138 CESCR https://tbinternet.ohchr.org/_layouts/15/treatybodyexternal/Download.aspx? symbolno=E\%2fC.12\%2fZAF\%2fCO\%2f1\&Lang=en 9 .

139 lbid.

140 See par 3 above.
} 
system falls short in a number of areas. In particular, ${ }^{141}$ the extent of coverage by social insurance ${ }^{142}$ and the use of social assistance benefits to realise other rights ${ }^{143}$ fall short of what is required in terms of the ICESCR. Since there has been no appreciable improvement in these areas since the release of the Concluding Remarks by the CESCR, it is submitted that South Africa is currently non-compliant with the ICESCR and needs to take meaningful steps in order to address the areas of concern as discussed above.

\section{Recommendations}

The high unemployment rate in South Africa is the greatest contributor towards a lack of access to social insurance. The implementation of a national social security fund has been mooted for a number of years by the state but has not yet come to fruition. The introduction of such a fund, with universal coverage for retirement benefits would substantially increase the level of coverage of social insurance benefits. The mechanisms of such a fund have never been published in great detail; best practice in countries with such universal funds would have to be considered, along with the input of economic experts to implement such a fund successfully.

The question of the use of social assistance benefits to realise other rights is not an easy one to answer. As mentioned above, South Africa is currently progressively realising this right within the available resources. How, then, can social assistance be used to more effectively realise other rights, such as the standard of living? It is submitted that social assistance grants can contribute more towards the realisation of other rights if other aspects of social security are improved. For example, the introduction of a functioning basic universal healthcare system would alleviate the burden of paying medical costs from the meagre amount currently paid to social grant recipients.

\footnotetext{
141 See par 3.5.1 above.

142 See par 3.4.2 above.

143 See par 3.6 above.
} 